\title{
RESEARCH ON TRANSNATIONALISATION OF ECONOMIC ACTIVITY INNOVATIVE COMPONENT INFLUENCED BY THE COVID-19 PANDEMIC
}

\author{
Tetiana Gavrilko', Lesya Pobochenko²
}

\begin{abstract}
The purpose of this article is to examine the innovative component of the transnationalisation of economic activity under the influence of the COVID-19 pandemic. Statistical and analytical systems analysis methods make it possible to determine the trend of research and development (R\&D) expenditures in the world over five years (2017-2021). Methodology. Research methods: theoretical generalization, analysis and synthesis, logical, system-structural analysis of economic processes and relations, statistical, comparative, sectoral and dialectical approaches. Results. In accordance with the theoretical study of the process of investment in innovation by TNCs under the influence of the COVID-19 pandemic, we conclude that innovation for multinational corporations is the realization of innovative and creative ideas, which are the basis of progress and profit. The balance of power in the global innovation space before and during the COVID-19 pandemic is demonstrated by examining the dynamics of innovation in countries and regions. Under the COVID-19 pandemic, companies' $R \& D$ spending has fluctuated slightly, while global $R \& D$ spending has increased. According to the Global R\&D Finance Forecast 2021, Asian countries, including China, will act as the engine of innovation in the coming years. Countries in the Americas and Europe will continue to lose their leadership in R\&D, even though their spending will rise as the overall global economy recovers. One of the key indicators of innovation development is the quota of expenditure on research and development in GDP in the world. The leaders in this indicator are South Korea, Israel, Japan, Finland, and Sweden. Practical implications. Innovation is recognized as a central factor in economic growth and development. Interest not only in the promotion but also in the evaluation of the results of innovation activities is growing not only in developed but also in developing countries. According to The Future of Post-COVID Innovation Finance GII (Global Innovation Index 2020/2021), the pandemic crisis had a short-term impact on innovation spending. Research and development (R\&D) spending in connection with the COVID-19 pandemic has always been high. In contrast to previous fears, the crisis has had only a minor impact on overall investment in innovation, as well as on the main consumers of innovation. At the company level, the COVID-19 pandemic has affected the industry distribution of innovation, but costs and access to innovation financing in developing countries and more volatile companies are at risk. Disparities in access to innovation finance are likely to intensify. Value/originality. The main international research units of TNCs are concentrated mainly in the United States, Western Europe, and Japan. But according to recent global trends, there is a possibility of creating new research units of transnational corporations in China and India, which will allow these two countries to become part of the "innovation core" of the world economy in the future.
\end{abstract}

Key words: global economy transnationalisation, global research and development costs, innovations, TNCs.

JEL Classification: F02, O32, O31, F21

\footnotetext{
Corresponding author:

${ }^{1}$ National Aviation University, Ukraine.

E-mail: tan3000@ua.fm

ORCID: https://orcid.org/0000-0002-2010-307X

ResearcherID: S-3805-2018

${ }^{2}$ National Aviation University, Ukraine.

E-mail: lesya.pobochenko50@gmail.com

ORCID: https://orcid.org/0000-0002-3094-6417

ResearcherID: G-7894-2019
} 


\section{Introduction}

The COVID-19 pandemic has caused numerous problems related to research and development worldwide in early 2020 . The pandemic crisis has added several more challenges to the annual research and development budget. The pandemic is not over, and no one knows how long it will last. Therefore, its impact on research and development efficiency will persist.

In the accelerated transformation of the "new economy" and the modern information society, one of the main competitive strategies of transnational corporations is the use of innovation as the most important intangible asset. Consequently, the competitive advantage of multinational companies in today's environment is the effective use of innovative factors.

One of the main sources of innovation possessed by TNCs is scientific, technological and human potential, which makes them major players in the formation of a global infrastructure of technological innovation. Thus, by carrying out investment activities, transnational corporations have a significant impact on the competitiveness of countries in the global economy, determining the leading positions of some and the dislocation of others. The share of transnational companies in global innovation production is higher than their share in financing research and development, and amounts to about $40-50 \%$ of global production.

When entering the international innovation market, TNCs integrate innovation activities throughout the structure of the main company, with affiliates of transnational corporations specializing in the most competitive innovations.

In the context of global transformations and new trends in innovative development, this is a "new world order in innovation," due to the growing role of Asian countries, especially China and India, which accumulate the largest corporate spending on research and development.

\section{Analysis of the innovative activity of modern transnational corporations in the context of the COVID-19 pandemic}

For the past year and a half, the world economy has been struggling with the effects of the COVID-19 pandemic. Workers are quarantined, research materials and supplies are delayed, transportation systems are cancelled, production lines are slowed, and interpersonal relationships have undergone major changes.

The 2021 Global R\&D Funding Forecast puts global R\&D investment at $\$ 2.32$ trillion in 2020 , down $2.1 \%$ from $\$ 2.37$ trillion in 2019. The think tank forecasts data for 115 countries that invest more than $\$ 20$ million in research and development at purchasing power parity (PPP). In 2021, this is expected to rise to $\$ 2.44$ trillion.

In 2019 , the $\mathrm{R} \& \mathrm{D}$ growth rate was higher by $4.1 \%$ compared to 2018 as a result of global economic growth, while the rate of R\&D decline in 2020 will be $2.1 \%$ due to the COVID-19 pandemic. It should be noted that due to the impact of the pandemic, the R\&D growth rate in 2021 will be $3.3 \%$.

The Global Funding Forecast for Multinational Companies' R\&D Investments is an annual report containing exclusive research results and estimates for the previous year, the current year, and the following year. The forecast has been published for 62 consecutive years since 1959. For forty years, these reports focused only on the United States because of its dominance in this arena. The first January 1959 report analyzed how $\$ 12$ billion would be spent by the U.S. Department of Research and Development in industry, government, and academia. The 62nd report now estimates where more than $\$ 2.44$ trillion will be invested in 2021.

Due to economic fluctuations and cycles, investment in $R \& D$ has changed several times over the past six decades. For example, when industrial investment declined during the year, public investment in $R \& D$ increased so much that total R\&D changed little (and vice versa)

Last year's 2020 Global R\&D Funding Forecast was completed months before the COVID-19 pandemic went global. As the pandemic spread around the world in the spring of 2020 and quarantine affected every aspect of global society, the editors of R\&D World updated the 2020 R\&D Funding Forecast, which was published in August 2020. As noted, the global R\&D outlook changed dramatically during 2020 as the worst economic predictions made at the beginning of the year failed to come true. At least part of this change was the result of vaccines being tested and introduced in many countries by the end of 2020 .

It is worth analyzing how the COVID-19 pandemic has changed $R \& D$ funding forecasts in the prepandemic period and during coronavirus infections. For example, the 2019 forecast (as of 01.01.2019) puts $\mathrm{R} \& \mathrm{D}$ investment at $\$ 2.37$ trillion. The forecast for 2019 (01.01.2019) is $\$ 2.37$ trillion with a global GDP of $\$ 137.8$ trillion. According to the COVID-19 pandemic 2020 forecast (01.01.2020), total global research and development spending was $\$ 2.43$ trillion and global gross domestic product reached \$141.7 trillion.

The updated 2020 forecast (07.12.2020) puts investment at $\$ 2.28$ trillion, down $\$ 0.1528$ trillion from the previous forecast. Global GDP is $\$ 132.5$ trillion, down $\$ 8.2$ trillion from the previous period. According to the actual results of 2020 (by 01.01.2021), the total global expenditure on research and development amounted to 
$\$ 2.32$ trillion. The world's gross domestic product reached $\$ 133.6$ trillion by the end of 2020 .

Global R\&D Funding Forecasts for 2021 show global R\&D spending rising to $\$ 2.44$ trillion this year, with an increase of about $\$ 12$ billion. Global GDP peaked at $\$ 140.5$ trillion, up $\$ 6.9$ billion from the previous period.

Global research and development prospects depend on the economies of individual countries. This impact tends to vary, especially if there is a pandemic. Forecasts of countries' gross $R \& D$ expenditures are also based on the historical economic distribution of R\&D. For example, China has been consistently investing heavily in R\&D for more than 20 years. Accordingly, although the country's economic growth has been limited by the pandemic (as has been seen in all other countries), the People's Republic of China's historic investment of about $10 \%$ annual growth led to R\&D growth in 2020. But almost every other country in the world, including the U.S., showed that their R\&D investment in 2020 was down from 2019.

In 2021, the U.S. is projected to cut its R\&D spending by $0.5 \%$ to $\$ 598.7$ billion. The important point here is that the overall U.S. share of global R\&D investment is declining. In contrast, elsewhere in the world, the cost of R\&D has begun to rise. The gap between Chinese and U.S. investment in $R \& D$ is expected to widen over the next few years.

For 20 years, the PRC has consistently demonstrated long-term growth in R\&D investment. The failure of the U.S. to match this growth has led to a projection that China will exceed the U.S. in R\&D for the first time in 2021 ( $\$ 621.5$ billion compared to China's $\$ 598.7$ billion). The $4 \%$ difference can be explained in part by the People's Republic of China's 2\% improvement in annual GDP compared to the U.S.'s 4\% decrease in annual GDP in 2020.
Ten years ago, the United States accounted for $34 \%$ of global R\&D investment, while the People's Republic of China accounted for $12.5 \%$. Today, the U.S. share is $24.5 \%$ and China's share is $25.5 \%$. While China will overtake the U.S. in research and development spending in 2021, India is projected to invest $\$ 93.48$ billion, surpass South Korea with $\$ 91.47$ billion in spending and move up one position in the most important consumers ranking (from sixth to fifth place). For years, India's GDP (\$10.87 trillion) has been higher than South Korea's (\$2.103 trillion). In other words, four times larger, primarily due to a larger population (25 times larger), but its $R \& D$ investment strategies are oriented toward lower costs than those of other large countries in the world. We can observe a significant improvement in India's investment policy over the last period (Table 1).

The six countries spending the most on R\&D in 2017-2021 are the US, China, Japan, Germany, India and South Korea, which account for almost $70 \%$ of all global R\&D investment. In 2020, the US and China will invest almost half (48.2\%) of all global $R \& D$ funds. Moreover, the US government (with its $\$ 580.2$ billion in R\&D funding) will spend more on $R \& D$ in 2020 than all other countries combined, except China and Japan.

The leading countries in research and development spending in 2020: the U.S. with a share of $25 \%$, in second place - China at $23.2 \%$, in third place - Japan with a share of $7.8 \%$. This is followed by Germany with a share of $5.3 \%$, India and South Korea with shares of $4 \%$ and $3.8 \%$, respectively. Investments in research and development in Russia account for about $3 \%$, which is also a significant indicator (Figure 1).

Over the past 5 years, the top 10 ranking has not changed significantly. Some countries have moved slightly up one position in the ranking, but at the

Table 1

Dynamics of global R\&D expenditures by region and leading countries in 2017-2020 and forecast for 2021, \%

\begin{tabular}{|c|c|c|c|c|c|}
\hline Country / region of the world & 2017 & 2018 & 2019 & 2020 & 2021 \\
\hline North America (12 countries) & 27,72 & 26,8 & 27,2 & 27 & 26,4 \\
\hline South America (10 countries) & 2,36 & 2,3 & 2,2 & 2,2 & 2 \\
\hline Asia (24 countries) & 42,67 & 43,5 & 43,9 & 44,3 & 46 \\
\hline Europe (34 countries) & 20,98 & 21,3 & 20,8 & 20,5 & 19,6 \\
\hline Russia / CIS ( 5 countries) & 2,87 & 2,8 & 2,7 & 2,7 & 2,6 \\
\hline Middle East $(13$ countries) & 2,5 & 2,5 & 2,4 & 2,4 & 2,3 \\
\hline Africa (18 countries) & 0,9 & 0,9 & 0,9 & 0,9 & 0,8 \\
\hline Total (116 countries) & $\mathbf{1 0 0}$ & $\mathbf{1 0 0}$ & $\mathbf{1 0 0}$ & $\mathbf{1 0 0}$ & $\mathbf{1 0 0}$ \\
\hline China & 21,16 & 21,8 & 22,5 & 23,2 & 25,5 \\
\hline The United States & 25,57 & 24,7 & 25,2 & 25 & 24,5 \\
\hline Japan & 8,82 & 8,3 & 8 & 7,8 & 7,5 \\
\hline Germany & 5,46 & 5,5 & 5,4 & 5,3 & 5,2 \\
\hline India & 3,66 & 3,9 & 4 & 4 & 3,8 \\
\hline South Korea & 4,06 & 3.9 & 3,8 & 3,8 & 3,78 \\
\hline Total (6 countries) & $\mathbf{6 8 , 7 3}$ & $\mathbf{6 8 , 2}$ & $\mathbf{6 8 , 9}$ & $\mathbf{6 9 , 1}$ & $\mathbf{7 0 , 3}$ \\
\hline
\end{tabular}

Source: Global R\&D Funding Forecast 2017-2021 


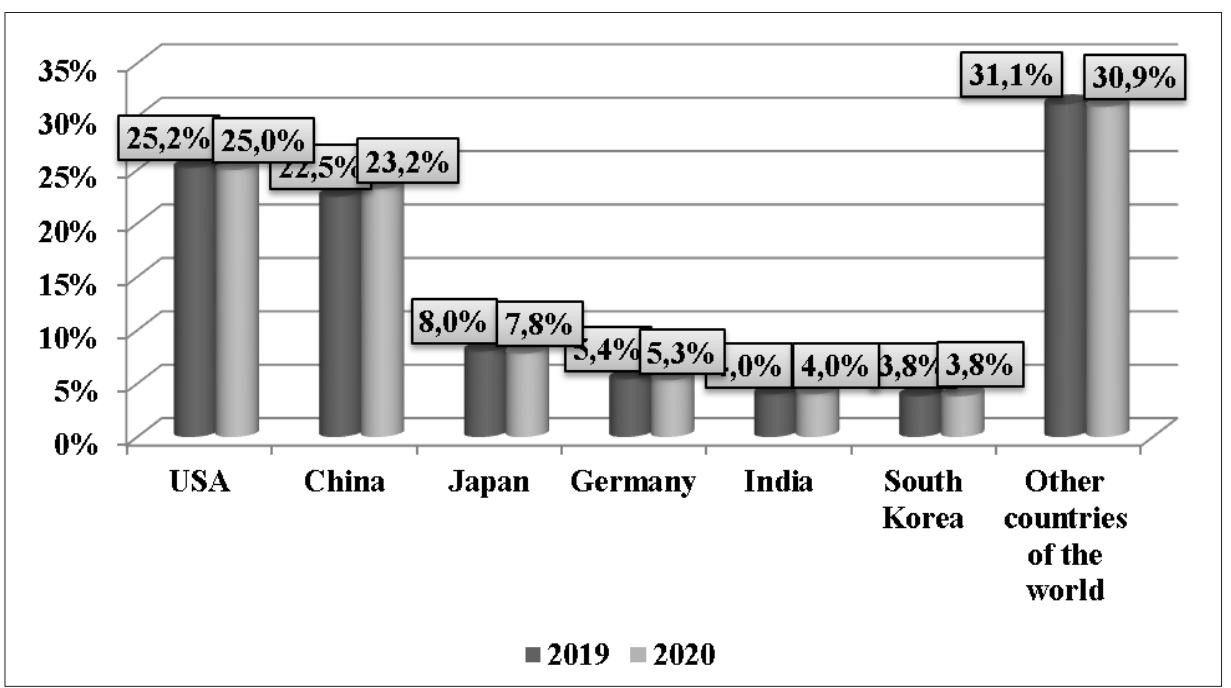

Figure 1. Investments of countries in research and development in 2019-2020, (\%)

Source: Global R\&D funding forecast 2019-2020

same time have maintained their relative position. For example, India is slowly moving up in the ranking and ranks 5th in 2020. While China has increased its research activities by almost $10 \%$ annually over the past 15 years, Japan has increased its R\&D investment by less than $2 \%$ a year. Finland, with a high ratio of researchers/population over 7,000, and Israel, with a high level of research as a percentage of GDP (4.0\%), are two historically stable representatives that have not changed over the past five years.

According to the report, $\mathrm{R} \& \mathrm{D}$ investment is spread around the world, but Asian countries continue to grow in the market, mainly thanks to increased investment in China. While US organizations have led the way in global spending for more than 50 years in a row.

According to the Global R\&D Funding Forecast 2021 , among the countries investing the most in R\&D in 2021, China will be in first place. In 2017-2020, the US ranked first. China's R\&D spending will exceed $\$ 621$ billion. The share of R\&D spending in global investment is $25.5 \%$ (Table 2).

Analysis of the above data shows that many countries are characterized by a decrease in $R \& D$ spending in 2020: for the United States, R\&D spending in 2020 fell by $2.75 \%$ compared with the 2019 level. According to expert estimates, in 2021, the US can only return to the level of 2019. As for the UK, France, Russia, Brazil and Japan, these countries are not expected to recover even to 2018 rates in 2021.

In 2020, China spent a record $2 \%$ of its gross domestic product (GDP) on research and development. The world's second-largest economy spent $\$ 574.4$ billion on R\&D. During the 13th five-year period (2016-2020), China's R\&D spending was

Table 2

Leading countries in global R\&D spending in 2017-2020 and forecast data for 2021, USD, billion

\begin{tabular}{|c|c|c|c|c|c|c|}
\hline Place & Country & 2017 & 2018 & 2019 & 2020 & 2021 \\
\hline 1 & China & 444,82 & 499,63 & 532,8 & 574,4 & 621,5 \\
\hline 2 & USA & 537,59 & 565,76 & 596,58 & 580,2 & 598,7 \\
\hline 3 & Japan & 185,54 & 189,51 & 190,65 & 181,1 & 182,36 \\
\hline 4 & Germany & 114,84 & 126,55 & 128,32 & 121,65 & 127,25 \\
\hline 5 & India & 76,91 & 89,23 & 95,79 & 85,92 & 93,48 \\
\hline 6 & South Korea & 85,43 & 89,47 & 90,27 & 87,11 & 91,47 \\
\hline 7 & France & 62,13 & 68,33 & 69,08 & 64,46 & 67,03 \\
\hline 8 & Russia & 57,81 & 61,58 & 61,43 & 58,92 & 60,57 \\
\hline 9 & Great Britain & 49,16 & 52,03 & 53,17 & 49,77 & 51,61 \\
\hline 10 & Brazil & 37,14 & 39,38 & 39,4 & 37,11 & 38,15 \\
\hline Top 10 leading countries & $\mathbf{1 6 5 1 , 3 7}$ & $\mathbf{1 7 8 1 , 4 7}$ & $\mathbf{1 8 5 7 , 5}$ & $\mathbf{1 8 4 0 , 6}$ & $\mathbf{1 9 3 2 , 1}$ \\
\hline All countries of the world & $\mathbf{2 1 0 3 , 5}$ & $\mathbf{2 1 8 9 , 6}$ & $\mathbf{2 3 7 0 , 8}$ & $\mathbf{2 3 2 5 , 2}$ & $\mathbf{2 4 4 0 , 5}$ \\
\hline
\end{tabular}

Source: Global R\&D Funding Forecast 2017-2021 
maintained at a constant annualized rate above $10 \%$ and exceeded 2,000 billion CNY for the first time in 2019. China's investment in $R \& D$ has increased its innovative power. In 2020, the country retained its 14th place in the list of the most efficient economies in the UN Global Innovation Index.

According to the Global R\&D Funding Forecast 2021, Asian countries, including China, will act as the engine of innovation in the coming years.

\section{Regional disparities in cost distribution at the NDCD in the context of the COVID-19 pandemic}

The correlation of forces in the global innovation space before and during the COVID-19 pandemic demonstrates the dynamics of innovative development indicators of countries and regions. In the face of a pandemic, Asia is the largest region for investment in research and development in 2020, with a $44.3 \%$ or $\$ 1,056$ trillion, share of global investment. The Asian region is growing by $0.5-2 \%$ annually in its total share of $R \& D$, and at this rate of growth, its share by 2030 could amount to more than half of all R\&D investments in the world.

Note that the share of North America $26.9 \%$ or $\$ 624.9$ trillion), including the US, and Europe (20.5\% or $\$ 457.3$ trillion) in world $\mathrm{R} \& \mathrm{D}$ expenditure has declined significantly due to the COVID-19 pandemic (Figure 2).

Influenced by the pandemic crisis in African countries, R\&D spending was $\$ 19.5$ billion in 2020, which was $\$ 1.1$ billion less than in 2019. Middle Eastern countries invested $\$ 53.5$ billion in R\&D in 2020 .
The Middle Eastern regions invested $\$ 53.5$ billion, $\$ 2.8$ billion less than Russia in 2019/UMP spending of $\$ 61.9$ billion. Most of these regions will return to 2019 values in 2021 .

Investment in $\mathrm{R} \& \mathrm{D}$ will continue to decline in Africa, South America and the Middle East. Their total $\mathrm{R} \& \mathrm{D}$ spending is only $5.1 \%$ of global $\mathrm{R} \& \mathrm{D}$ spending. But note that these three groups of countries account for about $13 \%$ of world GDP. Third-world countries, including many in South America and Africa, continue to lag behind in investment in $\mathrm{R} \& \mathrm{D}$, resulting in weaker economic growth. Overall, South America and Africa account for just $2.9 \%$ of total R\&D spending, even though they are home to more than $20 \%$ of the world's population.

Thus, the ratio of forces in the global innovation space is demonstrated by a study of the dynamics of innovative development of countries and regions. Of these, the share of countries in the Asian region is $45.4 \%$ and will continue to grow thanks to China. But the North American region's share, which is $26.9 \%$ in 2020, is significantly lower in global R\&D spending, including the US, and Europe's share (19.7\%).

\section{Estimation of the share of research and development expenditures in the GDP of countries affected by the coronavirus situation}

One of the main indicators of innovation development in TNCs is the share of $R \& D$ expenditures in the GDP of the world. Developed countries show high rates of innovation, which is the result of large investments in their $\mathrm{R} \& \mathrm{D}$. Thus, the share of spending on research and development in the leading

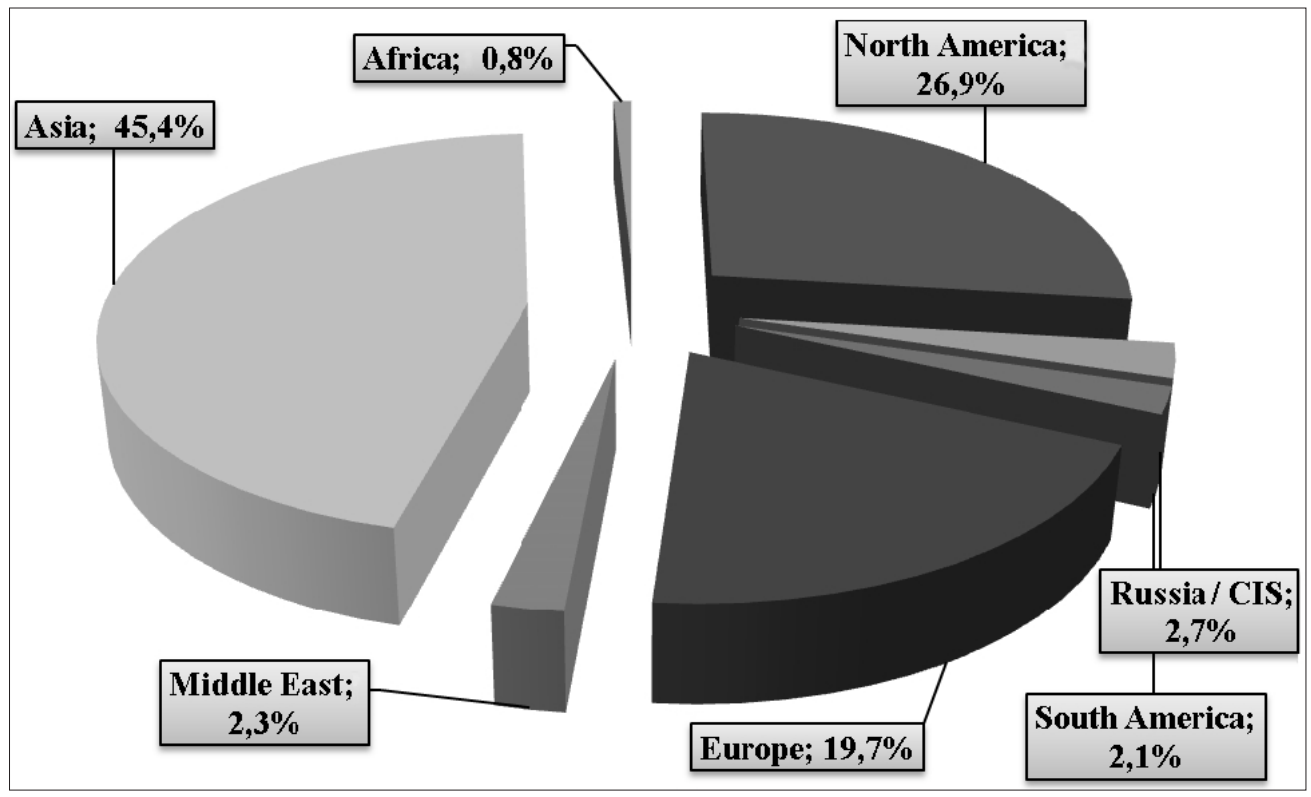

Figure 2. Regional distribution of global R\&D expenditures in 2020, (\%)

Source: Global R\&D Funding Forecast 2020 
countries is $2-3 \%$, in successful countries it is even $3-4 \%$ of GDP, and in the most successful it is more than $4 \%$ and has been growing exponentially for two decades.

Large investments in research and development are the basis for the creative knowledge that influences innovative decisions. North America has the highest level of R\&D spending as a share of GDP in 2020, at $2.5 \%$. In Europe, the share of $\mathrm{R} \& \mathrm{D}$ expenditures in GDP is $1.84 \%$, in some Asian countries it is $1.74 \%$, $1.24 \%$ in Russia/UMP, $0.77 \%$ in South America, 0.74\% in the Middle East, and $0.42 \%$ in Africa (Figure 3 ).

Under the influence of the COVID-19 pandemic, the regional structure of the largest investments in research and development is changing. North America, South America, and Europe are predicted to continue losing their R\&D leadership in 2021, even though their spending will grow as the overall global economy recovers. But there is an increase in the share of Asian countries and, in particular, China in 2021 in global $\mathrm{R} \& \mathrm{D}$, as well as an increase in research and development spending in these countries. In 2021, the share of China, Japan, India, and South Korea will reach 20\% of global investment in research and development in Asia and, consequently, the total GDP growth - up to $\$ 4$ trillion.

According to recent research, the positive outlook for the global economy in 2021 is largely the result of the success of COVID-19 vaccination. The vaccination schedule allowed the drugs to be developed, a full series of trials, regulatory approval, production, and worldwide distribution to begin in less than a year. Vaccination in the first half of 2021 is projected to set the foundation for a strong rebound in the second half of the year. Economists expect a return to the pandemic period by mid-2021 or late summer. Emerging markets are expected to benefit more from the recovery in 2021, and their growth rates will be higher than in developed countries.

One of the main indicators of the development of innovation activity of TNCs is the share of spending on research and development in GDP. Some countries may have a lower GDP than others, but spend more on R\&D and therefore have a higher percentage of GDP on investment in $\mathrm{R} \& \mathrm{D}$.

As for the types of R\&D, historically (before World War II) they were divided into three sections: basic research, applied research, and development. The fourth aspect, "Applied Development," which deals with specific efforts to bring products to market, began to be discussed relatively recently.

The leader in the share of spending on $\mathrm{R} \& \mathrm{D}$ in global GDP in 2020 is South Korea with a share of 4.35\% of the country's GDP, followed by Israel (4.04\%), Japan (3.5\%), Finland (3.5\%), and Sweden (3.28\%). Also among the leaders are Denmark (3\%), Austria (2.98\%), Switzerland (2.97\%), Germany, and the United States - $2.84 \%$ each. According to the forecast data, the share of spending on research and development in GDP in 2020 will not change (Figure 4).

Thus, one of the main indicators of innovation development and the general characteristic of the national innovation system in the economy of countries is the share of research and development costs in GDP. In 2020, South Korea, Israel, Japan, Finland and Sweden were the leaders in terms of the share of investment in research and development in GDP.

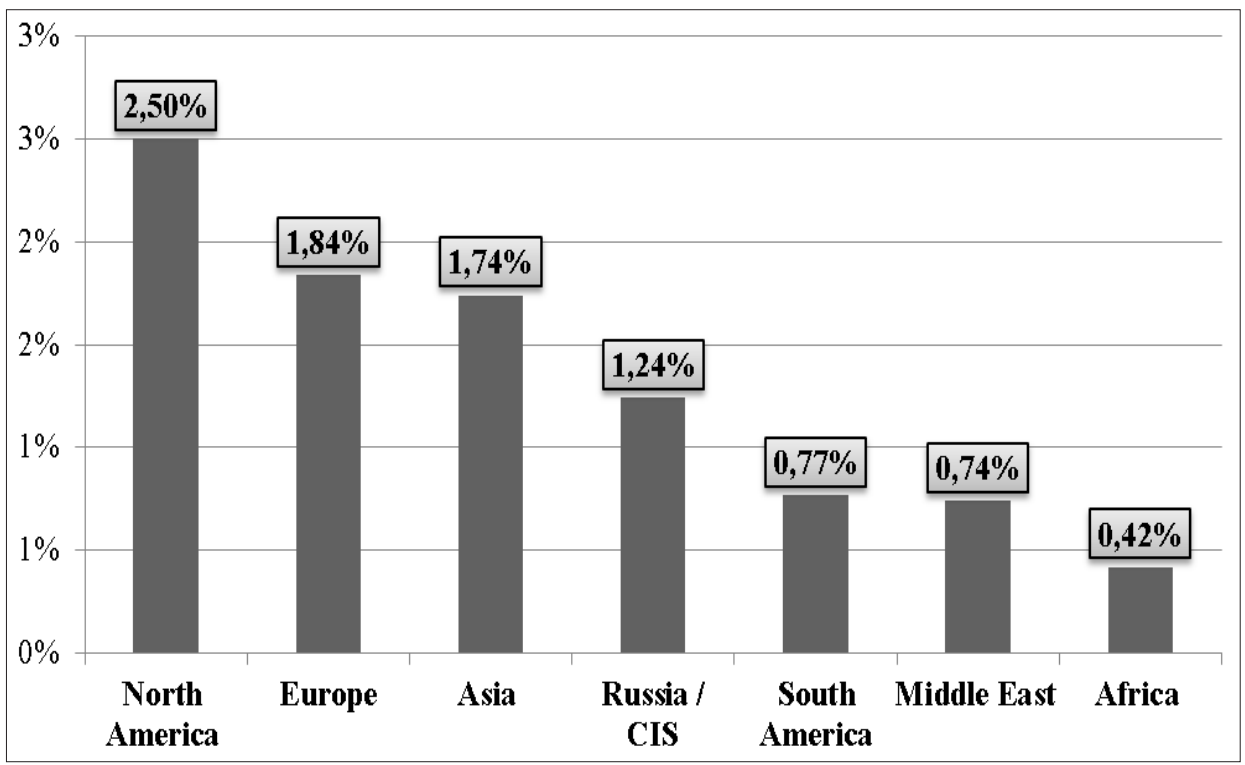

Figure 3. Regional distribution of R\&D expenditures in GDP in 2020, (\%)

Source: Global R\&D Funding Forecast 2020 


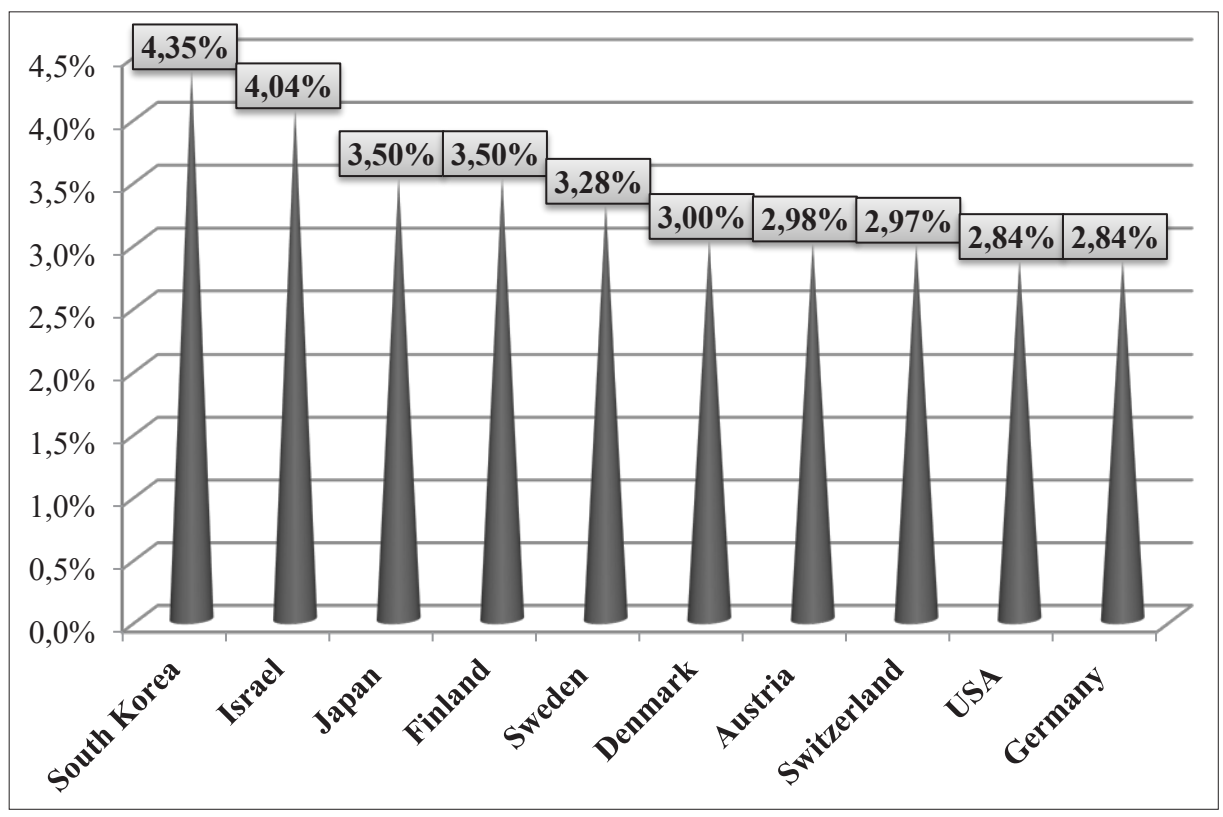

Figure 4. Share of R\&D expenditure in global GDP in 2020, (\%)

Source: Global R\&D Funding Forecast 2020

\section{Findings}

In times of pandemic, the dynamic development of countries is impossible without the use of one of the most important competitive advantages of TNCs and a strategic imperative for the development of the world economy - innovation. Their effective use is becoming a top priority for TNCs in the XXI century.

According to the study, the main international research units of TNCs are concentrated mainly in a closed circle of countries, namely the United States, Western Europe and Japan. According to recent global trends, there is a possibility of new research units of multinational corporations in China and India, which will allow these two countries to enter the "innovation core" of the world economy in the future.

Analyzing the process of investment in innovation of TNCs under the influence of the COVID pandemic, it is proved that innovation for multinational corporations is the implementation of innovative and creative ideas, which are the basis of progress and aimed at generating profits for companies.

Innovation is recognized as a central factor in economic growth and development. Accordingly, there is growing interest not only in the promotion but also in the evaluation of the results of innovation in both developed and developing countries.

It has been noted that access to $\mathrm{R} \& \mathrm{D}$ funding is unequal between countries/regions (the US, China, India, Europe, North America, Asia). It is necessary to find a balance between underinvestment and overinvestment in R\&D.

Today, innovators use a variety of sources of research and development funding, including from new entities such as non-profit organizations and foundations. Traditional mechanisms for financing innovation include state support schemes, firm-specific investments in innovation, and market-based mechanisms that focus specifically on innovation, such as loans, direct investment, and venture capital. New mechanisms include corporate risk, intellectual property markets, microfinance, crowdfunding, and technology solutions.

According to the study, the pandemic crisis had only a minor impact on innovation spending, as well as on the main consumers of innovation. At the company level, the COVID-19 pandemic has affected the industry distribution of innovation. Also at risk are the costs of innovation in developing countries and more unstable companies. An increased imbalance in access to funding for innovation is possible.

\section{References:}

Lorena Rivera Leon, \& Sacha Wunsch-Vincent (2021). The Future of Post-COVID Innovation Finance Global Innovation Index 2020/2021. World Intellectual Property Organization (WIPO), 3, 14. Available at: https://www.wipo.int/ export/sites/www/econ_stat/en/economics/pdf/2021_un_sti_forum.pdf (accessed 12 September 2021).

R\&D WORLD (2019). Global R\&D Funding Forecast 2019. R\&D Magazine, p. 36. Available at: http://digital.rdmag.com (accessed 10 September 2021).

R\&D WORLD (2020). Global R\&D Funding Forecast 2020. R\&D Magazine, p. 67. Available at: http://digital.rdmag.com (accessed 10 September 2021). 
R\&D WORLD (2021). Global R\&D Funding Forecast released 2021. R\&D Magazine. Available at: https://www.rdworldonline.com/2021-global-rd-funding-forecast-released/ (accessed 10 September 2021).

Paul Heney (2021). Pandemic disrupts flow of Global R\&D. Global R\&D funding forecast, 2(1), 6-22. Available at: https://www.rdworldonline.com/2021-global-rd-funding-forecast-released/ (accessed 12 September 2021).

Pavlovych, O. R. (2018). Osoblyvosti upravlinnya innovatsiyamy v TNK [Features of innovation management in TNCs]. Market economy: modern theory and practice of management, 17(2), 108-118.

Pobochenko, L. M. (2019). Otsinka innovatsiynykh pozytsiy TNK rozvynenykh krayin svitu [Evaluation of innovative positions of TNCs in developed countries]. International relations: theoretical and practical aspects, 4, 91-103.

Pobochenko, L. M. (2018). Innovatsiina skladova transnatsionalizatsii ekonomichnoi diialnosti v umovakh hlobalizatsiinykh peretvoren [Innovative component of transnationalisation of economic activity in the conditions of globalization transformations]. Development Strategy of Ukraine (Economics, Sociology, Law), 2, 71-77. 